\title{
Dinamika Pelajaran Sejarah Indonesia dalam Kurikulum 2013 pada Jenjang SMK/MAK
}

\author{
Rinaldo Adi Pratama, Maskun, Nur Indah Lestari \\ Program Studi Pendidikan Sejarah, Universitas Lampung \\ Email: rinaldo.adipratama@fkip.unila.ac.id
}

\begin{abstract}
This study aims to explain the dynamics of Indonesian History subject in the 2013 Curriculum at Vocational High School. Implementation of the 2013 Curriculum, the Indonesian History subject had a special place at the Vocational High School level. But, revision of 2013 Curriculum effected on the existence of Indonesian History subject in Vocational High School. This study used a library research method that used library resources in research without field research. The results showed that Indonesian History subject at the beginning of the 2013 Curriculum implementation got allocation 216 hours for six semester in $10^{\text {th }}, 11^{\text {th }}$, and $12^{\text {th }}$ grade. Decreased to 144 hours for four semester in 10 th and $11^{\text {th }}$ grade after revised in 2016, and decreased again to 108 hours of time allocation for two semester only in $10^{\text {th }}$ grade in 2017 and changing nomenclature from Indonesian History become History.
\end{abstract}

Keywords: 2013 Curriculum, Indonesian History Subject, Vocational High School

\begin{abstract}
Abstrak: Tulisan ini bertujuan untuk memaparkan mengenai dinamika pelajaran Sejarah Indonesia dalam Kurikulum 2013 di jenjang SMK/MAK. Seperti diketahui bahwasanya awal penerapan Kurikulum 2013, Sejarah Indonesia mendapatkan tempat istimewa pada jenjang SMK/MAK, namun seiring perkembangan waktu, terjadi revisi yang dilakukan terhadap Kurikulum 2013 yang berdampak pada keberadaan mata pelajaran Sejarah Indonesia yang semakin berkurang jumlah jamnya. Penelitian ini menggunakan metode historis yang mencakup heuristik, kritik, interpretasi dan historiografi. Hasil penelitian menunjukan bahwa Sejarah Indonesia pada awal penerapan Kurikulum 2013 mendapatkan alokasi waktu 216 jam pelajaran, semakin berkurang menjadi 144 jam pelajaran setelah terjadi revisi kurikulum pada 2016 dan semakin berkurang lagi menjadi 108 jam pelajaran serta perubahan komenklatur dari Sejarah Indonesia menjadi sejarah setelah perbaikan struktur kurikulum untuk SMK/MAK pada tahun 2017.
\end{abstract}

Kata Kunci: Kurikulum 2013, Sejarah Indonesia, SMK/MAK

\section{PENDAHULUAN}

Undang-Undang No. 20 Tahun 2003 menjabarkan bahwa pendidikan bertujuan mengoptimalkan potensi peserta didik agar menjadi manusia yang beriman dan bertakwa kepada Tuhan Yang Maha Esa, berakhlak mulia, sehat, berilmu, cakap, kreatif, mandiri, dan menjadi warga negara 
yang demokratis serta bertanggung jawab (Wijayanti, 2017). Oleh sebab itu pendidikan merupakan sarana terpenting dalam mewujudkan cita-cita bangsa dan pembelajaran sejarah bisa menjadi salah satu jalan dalam rangka mencapai tujuan tersebut (Alfian, 2011).

Tidak dapat dipungkiri bahwa pembelajaran sejarah mempunyai fungsi yang sangat penting dalam membentuk kepribadian bangsa, kualitas manusia dan masyarakat Indonesia umumnya. Namun yang menjadi permasalahan sampai dengan saat ini yakni, keberhasilan dari pembelajaran sejarah masih terus dipertanyakan. Dengan kenyataan tersebut artinya ada sesuatu yang harus dibenahi dalam pelaksanaan pembelajaran sejarah.

Said Hamid Hasan memberikan pandangannya terkait kenyataan yang ada bahwa pengajaran sejarah masih jauh dari apa yang harapan untuk memungkinkan peserta didik melihat relevansinya dengan kehidupan masa kini dan masa depan (Hasan, 1994). Hal tersebut dapat dilihat bahwa mulai dari jenjang SD hingga SLTA, pembelajaran sejarah cenderung hanya mengedepankan urutan fakta sejarah sebagai materi utama. Maka, Tidaklah mengherankan jikalau proses belajar sejarah terasa kering bahkan tidak menarik dan guru tidak memberi kesempatan kepada anak didik untuk belajar menggali makna dari sebuah peristiwa sejarah.

Lalu bagaimana strategi untuk dapat mencapai tujuan pendidikan tersebut? Tentu dalam pembelajaran salah satu komponen yang menjadi acuan untuk mencapai tujuan pendidikan nasional tersebut adalah kurikulum. Maksudnya di sini adalah kurikulum memiliki arti penting untuk menjadi acuan strategi pedagogis, agar cita-cita mencerdaskan kehidupan bangsa seperti yang diamanatkan Undang-Undang Dasar 1945 dapat terwujud. 
Terkait dengan hal tersebut di atas, pemerintah mencoba untuk memperbaiki kurikulum yang sedang berjalan yakni Kurikulum Tingkat Satuan Pendidikan (KTSP) atau Kurikulum 2006 dengan Kurikulum 2013. Dalam pengembangannya Kurikulum 2013 memiliki tujuan untuk mempersiapkan manusia Indonesia agar memiliki kemampuan hidup sebagai pribadi dan warga negara yang beriman, produktif, kreatif, inovatif, dan afektif serta mampu berkontribusi pada kehidupan bermasyarakat, berbangsa, bernegara, dan peradaban dunia.

Semenjak diberlakukannya Kurikulum 2013 pada tahun ajaran 2013/2014 oleh pemerintah terdapat hal yang sungguh menarik untuk dilihat lebih jauh, yakni keberadaan mata pelajaran Sejarah Indonesia yang mendapatkan porsi cukup besar pada Kurikulum 2013. Ditengahtengah kenyataan di lapangan dari para peserta didik akan ketidaktertarikan terhadap mata pelajaran sejarah (Suswandari, 2010). Mata pelajaran Sejarah Indonesia wajib diajarkan baik pada jenjang Sekolah Menengah Atas (SMA) maupun Sekolah Menengah Kejuruan (SMK) dan Sejarah Peminatan di SMA, yang menjadi menarik adalah, bagaimana jenjang SMK tidak ketinggalan mendapatkan porsi yang sama dengan SMA. Hal ini menandakan munculnya keseriusan pemerintah untuk mewujudkan cita-cita pendidikannya melalui mata pelajaran Sejarah Indonesia.

SMK adalah salah satu bentuk satuan pendidikan formal di bawah naungan Kementerian Pendidikan dan Kebudayaan yang menyelenggarakan pendidikan kejuruan atau vokasional pada jenjang pendidikan menengah sebagai lanjutan dari tingkat SMP sederajat. Apabila di SMA hanya ada tiga jurusan yakni IPA, IPS, dan Bahasa, sedangkan pada jenjang SMK terdapat sembilan bidang keahlian, yang 
dipecah kembali menjadi beberapa Program Studi Keahlian dan dispesialisasi lagi menjadi kompetensi keahlian.

Penting untuk diketahui bahwa proses pembelajaran pada jenjang SMK lebih menekankan keterampilan dan mata pelajaran produktifnya karena luarannya adalah siap kerja atau berwirausaha. Hal ini senada dengan pandangan Evans dan Edwin (1978). Pendidikan kejuruan adalah bagian dari sistem pendidikan yang mempersiapkan seseorang agar lebih mampu bekerja pada satu kelompok pekerjaan atau satu bidang pekerjaan daripada bidang-bidang pekerjaan lainnya. Menurut penjelasan UndangUndang Nomor 20 Tahun 2003 Pasal 15, pendidikan kejuruan merupakan pendidikan menengah yang mempersiapkan peserta didik terutama untuk bekerja dalam bidang tertentu. Pendidikan kejuruan terdiri dari Sekolah Menengah Kejuruan, dan Madrasah Aliyah Kejuruan.

Pemerintah telah meluncurkan dan menerapkan Kurikulum 2013 yang menempatkan mata pelajaran Sejarah Indonesia sebagai mata pelajaran wajib di jenjang SMA/MA/SMK/MAK. Sebelumnya dalam kurikulum KBK 2004 maupun KTSP 2006 Sejarah Indonesia tidaklah berdiri sendiri sebagai mata pelajaran melainkan terpadu dalam mata pelajaran Ilmu Pengetahuan Sosial (IPS) bersama dengan Ekonomi dan Geografi. Berdasarkan Peraturan Menteri Pendidikan dan Kebudayaan No. 70 tahun 2013, mata pelajaran Sejarah Indonesia menjadi mata pelajaran wajib yang harus ditempuh oleh semua peserta didik di jenjang pendidikan menengah, tanpa memandang penjurusan atau peminatan yang diambilnya termasuk di jenjang sekolah vokasional. Hal ini secara tidak langsung ingin menunjukkan begitu pentingnya posisi dan peran mata pelajaran Sejarah Indonesia dalam pembinaan peserta didik sebagai generasi muda bangsa. 
Pada awal peluncuran dan pelaksanaan Kurikulum 2013, mata pelajaran Sejarah Indonesia di SMK memiliki struktur kurikulum dan porsi yang sama seperti di jenjang SMA (Agustinova, 2018). Sekolah SMK memiliki karakteristik tersendiri, berbeda dengan SMA. Namun setelah ada revisi porsi mata pelajaran Sejarah Indonesia pun berkurang dari yang awalnya 216 jam pelajaran (JP) dengan perhitungan 2 JP x 6 Semester menjadi 144 jam pelajaran atau 2 JP x 4 semester setelah mengalami revisi kurikulum pada tahun 2016. Setahun kemudian terjadi perubahan kembali pada struktur kurikulum SMK melalui Surat Keputusan Direktur Jenderal Pendidikan Dasar dan Menengah dan mata pelajaran Sejarah Indonesia mengalami pengurangan lagi menjadi $108 \mathrm{JP}$ atau 3JP x 2 semester.

Tulisan ini ingin melihat bagaimana posisi mata pelajaran Sejarah Indonesia dengan dinamikanya dari mulai diterapkannya Kurikulum 2013 hingga implementasinya dengan berbagai dinamika yang ada dalam pendidikan vokasi yang penuh dengan perubahan karena tuntutan dunia usaha dan dunia industri (DU-DI) yang menjadi ciri khas dari SMK. Tuntutan zaman juga mendorong terus terjadinya perubahan-perubahan dalam spektrum keahlian dan spektrum kurikulum pada jenjang SMK.

\section{METODE PENELITIAN}

Penulisan artikel ini menggunakan metode sejarah. Metode sejarah merupakan sebuah proses untuk menguji dan menganalisis secara mendalam berdasarkan data yang didapatkan (Gottschalk, 1975). penelitian ini menggunakan metode penelitian historis yang meliputi heuristik, kritik, interpretasi dan historiografi (Sjamsuddin, 2012). 
Pada tahap heuristik atau pengumpulan data, peneliti melakukan pencarian sumber yang berkaitan dengan objek yang diteliti. Penelurusan sumber dilakukan melalui penelitian di perpustakaan, literatur diperoleh melalui studi pustaka di perpustakaan Universitas Lampung, melakukan wawancara mendalam terhadap ketua MGMP Sejarah Bandar Lampung, ketua MGMP Sejarah Provinsi Banten serta wawancara kepada pengembang Kurikulum 2013.

Tahap selanjutnya yaitu tahap kritik intern dan ekstern dilakukan dengan membuat perbandingan dari beberapa sumber dan membandingkannya dengan fakta-fakta yang ada sebelumnya. Tahap selanjutnya yakni interpretasi atau penafsiran berdasarkan sumber yang telah didapat, dilakukan berdasarkan fakta dan juga data yang diperoleh sehingga tidak hanya imajinasi semata untuk itu peneliti mencantumkan sumber data yang digunakan. Pada tahap interpretasi sumber-sumber primer yang telah didapatkan dilakukan komparasi dengan sumbersumber lain baik sekunder ataupun tersier. Hal ini dilakukan agar tidak ada kesalahan pemaknaan. Pada tahap interpretasi ini peneliti berusaha untuk mengkaitkan antara fakta yang satu dengan fakta lainnya, sehingga diperoleh sebuah gambaran peristiwa secara utuh dan kronologis serta saling berkaitan.

Tahap terakhir dalam metode ini yakni historiografi yaitu penulisan. Penulisan sejarah disusun secara kronologis dan memperhatikan aspek kausalitas. Pembahasan mengenai implementasi kurikulum 2013 yang memuat pelajaran Sejarah Indonesia pada jenjang pendidikan SMK/MAK dengan porsi yang sama dengan SMA/MA, namun dalam perjalanannnya mengalami perubahan yang mana pelajaran sejarah Indonesia terus 
berkurang alokasi waktu pada revisi terakhir 2017 untuk jenjang SMK/MAK.

Dengan menggunakan metode sejarah, penulis mendapatkan panduan banagimana secara teknis artikel ini dapat dikerjakan secara efektif dan akurat. Penulis menggunakan term kurikulum 2013 mulai dari pertama kali diterapkan pada tahun 2013 sampai dengan revisi terkahir pada tahun 2017 yang memberikan perubahan drastis pada mata pelajaran Sejarah Indonesia pada jenjang SMK/MAK.

\section{HASIL}

Kurikulum merupakan seperangkat rencana dan pengaturan mengenai tujuan, isi, dan bahan pelajaran serta cara yang digunakan sebagai pedoman penyelenggaraan kegiatan pembelajaran untuk mencapai tujuan pendidikan tertentu (Sulaiman, 2012). Berdasarkan pengertian tersebut di atas, setidaknya terdapat dua dimensi kurikulum, yang pertama adalah perencanaan dan pengaturan mengenai tujuan, isi, dan bahan pelajaran, sedangkan yang kedua adalah cara yang digunakan untuk kegiatan pembelajaran.

Kurikulum 2013 yang diberlakukan pertama kali mulai tahun ajaran 2013/2014 memenuhi kedua dimensi tersebut di atas. Sebelum dilakukan analisis terkait dinamika mata pelajaran Sejarah Indonesia di dalam Kurikulum 2013, perlu kiranya dilihat terlebih dulu mengapa KTSP harus diganti dengan Kurikulum 2013 terlepas dari soal pro dan kontra di lapangan, Kurikulum 2013 secara konsep layak untuk dilaksanakan namnun disayangkan dalam penerapannya terkesan tergesa-gesa sehingga kesiapan-kesiapan menjadi kurang matang, termasuk penyiapan guru dan bahan ajarnya (Sardiman, 2015). Lalu mengapa Kurikulum 2013 dikembangkan dan diterapkan di Indonesia? Hal ini dikarenakan 
penyempurnaan kurikulum adalah sebuah keniscayaan dan keharusan, mengingat adanya tantangan baru, baik secara internal maupun eksternal.

\section{Pelajaran Sejarah Indonesia dalam Kurikulum 2013 Awal}

Sejarah dan pembelajaran sejarah dilingkup pendidikan memiliki makna yang sangat penting bagi wujud dan keberlanjutan suatu bangsa (Suswandari, 2010). Salah satu manfaat besar setelah mempelajari sejarah antara lain menjadikan sejarah sebagai salah satu cermin untuk mengarahkan perkembangan di masa datang, menjadikan peristiwa masa lalu sebagai pedoman untuk menjalani masa yang akan datang, bukan sebatas menghapal peristiwa sejarahnya saja.

Pengembangan Kurikulum 2013 diawal mengharapkan dapat mewujudkan komptensi lulusan yang mampu memahami dan mencari solusi berbagai permasalahan yang terkait dengan berbagai tantangan. Misalnya kompetensi yang terkait dengan kemampuan berpikir jernih dan mendasarkan pada pertimbangan moral, kemampuan berpikir kritis dan kreatif, atau memiliki kecerdasan intelektual, sosial/emosional dan spiritual, kemampuan berkomunikasi, kemampuan menjadi warga negara yang demokratis dan bertanggungjawab serta peduli dan toleran terhadap sesama dan lingkungan

Terkait dengan dengan berbagai tantangan tersebut di atas, secara filosofis penyelenggaraan pendidikan dan pengembangan Kurikulum 2013 perlu didasarkan pada akar budaya bangsa (Pancasila) yang dapat mendorong terjadinya proses pewarisan dan pengembangan budaya, memberikan dasar bagi keberlanjutan kehidupan bangsa dengan segala aspek kehidupan yang mencerminkan karakter bangsa masa kini dan masa yang akan datang, eklektik antara perenialisme, esensialisme, humanism, progresivisme dan rekonstruksi sosial (Hasan, 2013). 
Struktur kurikulum untuk Sejarah Indonesia di SMK/MAK berdasarkan Peraturan Menteri Pendidikan dan Kebudayaan No 70 Tahun 2013 tentang Kerangka Dasar dan Struktur Kurikulum Sekolah Menengah Kejuruan/Madrasah Aliyah Kejuruan menjelaskan bahwa mata pelajaran sejarah yang terbagi menjadi dua, yakni Sejarah Indonesia (kelompok wajib) dan Sejarah Peminatan (kelompok minat) untuk di jenjang SMK/MAK hanya menerapkan mata pelajaran Sejarah Indonesia dengan porsi untuk SMK/MAK sederajat sama dengan jenjang SMA/MA sederajat yakni 2 jam pelajaran per minggu dan diberikan di kelas X, XI, dan XII.

Dari isi Permendikbud di atas, dapat disimpulkan artinya untuk SMK/MAK mata pelajaran Sejarah Indonesia mendapatkan jumlah total 216 jam pelajaran selama enam semester atau tiga tahun belajar di SMK/MAK. Dengan kondisi seperti itu, artinya pembelajaran Sejarah Indonesia di SMK/MAK tidak ada bedanya sama sekali dengan di SMA/MA. Berikut ini tersaji gambar tabel struktur Kurikulum 2013 awal untuk SMK/MAK.

Struktur kurikulum SMK/MAK terbagi dalam tiga kelompok, yaitu Kelompok A (Wajib), Kelompok B (Wajib), dan Kelompok C (Peminatan), istilah ini menggantikan istilah lama di SMK dengan sebutan kelompok mata pelajaran Adaptif, Normatif, dan Produktif. Mata pelajaran Sejarah Indonesia dalam Kurikulum 2013 awal termasuk kedalam rumpun mata pelajaran Kelompok A (Wajib) bersamaan dengan lima mata pelajaran lainnya yakni Pendidikan Agama dan Budi Pekerti, PPKn, Bahasa Indonesia, Matematika, dan Bahasa Inggris. Alokasi waktu untuk mata pelajaran Sejarah Indonesia yakni 2 jam pelajaran per minggu dan diberikan di kelas X, XI, dan XII. Satu jam pelajaran perminggunya adalah 45 menit, alokasi waktu yang diberikan oleh pemerintah untuk Sejarah Indonesia di SMK/MAK ini tidak ada bedanya sama sekali dengan alokasi waktu Sejarah Indonesia yang diterapkan di sekolah umum SMA/MA. Hal ini menunjukan bagaimana pemerintah ingin membangun masyarakat yang mampu 
berpikir kritis dan mewujudkan cita-cita pendidikannya melalui peserta didik yang belajar dari sejarah.

Struktur Kurikulum SMK/MAK merupakan pengorganisasian atas kompetensi inti, mata pelajaran, beban belajar, dan kompetensi dasar pada setiap SMK/MAK dirancang dengan pandangan bahwa SMA/MA dan SMK/MAK pada dasarnya adalah pendidikan menengah, pembedanya hanya pada pengakomodasian minat peserta didik saat memasuki pendidikan menengah. Oleh karena itu, struktur umum SMK/MAK sama dengan struktur umum SMA/MA, yakni ada tiga kelompok Mata pelajaran: Kelompok A, B, dan C.

Setelah mengetahui struktur kurikulum Sejarah Indonesia di SMK/MAK, pemerintah membagi organisasi materi dalam Kurikulum 2013 untuk mata pelajaran Sejarah Indonesia. terdapat istilah baru untuk menggantikan istilah dari Standar Kompetensi (SK) dan Kompetensi Dasar (KD) yakni dengan Kompetensi Inti (KI) dengan Kompetensi Dasar (KD). Dalam Kurikulum 2013 ini, pemerintah membuat empat KI yang nantinya dikembangkan dalam beberapa KD. Adapun KI-KD dan pengorganisasian materi dapat dilihat dalam tabel berikut ini:

Tabel 1. Organisasi Materi Berdasarkan KI-KD Kurikulum 2013 Awal

\begin{tabular}{lll}
\hline \multicolumn{1}{c}{ Kelas X } & \multicolumn{1}{c}{ Kelas XI } & \multicolumn{1}{c}{ Kelas XII } \\
\hline \multicolumn{1}{c}{ KI 1 berjumlah 2 KD } & KI 1 berjumlah 1 KD & KI 1 berjumlah 1 KD \\
KI 2 berjumlah 3 KD & KI 2 berjumlah 5 KD & KI 2 berjumlah 3 KD \\
KI 3 berjumlah 8 KD & KI 3 berjumlah 11 KD & KI 3 berjumlah 9 KD \\
KI 4 Berjumlah 8 KD & KI 4 Berjumlah 11 KD & KI 4 Berjumlah 9 KD \\
\hline Materi: & Materi: & Materi: \\
1. Konsep berpikir diakronik, & 1. Kolonialisme Barat di & 1. Disintegrasi Bangsa \\
sinkronik, ruang, waktu & Indonesia & 2. Demokrasi Liberal \\
dalam sejarah & 2. Pergerakan Nasional & 3. Demokrasi Terpimpin \\
2. Masa praaksara & 3. Proklamasi & 4. Orde Baru \\
3. Masa Hindu-Buddha & 4. Revolusi Kemerdekaan & 5. Reformasi \\
4. Masa Kerajaan Islam & & 6. Peran Indonesia dalam \\
& & perdamaian dunia \\
\hline
\end{tabular}

Secara substansial, KI didesain dalam empat kelompok yang saling terkait, yaitu berkenaan dengan sikap spiritual KI-1, sikap sosial KI-2, 
pengetahuan KI-3, dan keterampilan/penerapan pengetahuan KI-3. Sedangkan Kompetensi Dasar merupakan kompetensi setiap mata pelajaran untuk setiap kelas yang diturunkan dari Kompetensi Inti. Kompetensi Dasar adalah kompetensi dan konten yang juga terkait dengan aspek spiritual, sikap sosial, pengetahuan, dan ketrampilan yang bersumber pada Kompetensi Inti yang harus dikuasai peserta didik. Menarik untuk melihat KD yang terdapat di kelas XI bagaimana pemerintah dalam Kurikulum 2013 tidak mencantumkan secara tersurat materi Pendudukan Jepang di Indonesia.

Kurikulum 2013 dalam Sejarah Indonesia juga dari KI dan KD terlihat lebih menekankan pengembangan pemikiran kritis-kreatif dan inovatif bagi peserta didik. Peserta didik juga dikembangkan rasa ingin tahu, peserta didik tidak lagi harus diberi tahu atau menerima pengetahuan tetapi bagaimana mereka itu dilatih mencari dan menemukan pengetahuan. Sumber belajar tidak hanya terbatas guru tetapi bisa siapa dan apa saja yang relevan. Tempat pembelajaran tidak terbatas di ruangan kelas tetapi di masyarakat dan lingkungan alam. Oleh karena itu, secara metodologis, dalam pembelajaran pada Kurikulum 2013 menekankan pendekatan saintifik. Pada peserta didik dikembangkan kemampuan mengamati dan menanya, kemampuan mengumpulkan informasi, berikut mengasosiasi atau mengolah informasi sampai menarik kesimpulan dan kemudian mengkomunikasikan hasil.

\section{Pelajaran Sejarah Indonesia dalam Kurikulum 2013 Revisi 2016}

Selang tiga tahun setelah berjalannya Kurikulum 2013 pada awal tahun ajaran baru 2013/2014 berjalan ditambah dengan masih diwarnai pro-kontra atas penerapan Kurikulum 2013, pada tahun 2016 pemerintah dalam hal ini Kementerian Pendidikan dan Kebudayaan melakukan revisi 
terhadap Kurikulum 2013 dalam beberapa aspek. Setidaknya terdapat empat aspek yang direvisi pada tahun 2016 yakni: Pertama, Penataan KI 1 dan KI 2. Kedua, Koherensi KD pada setiap mata pelajaran. Ketiga, Pendekatan Saintifik yang lebih luwes. Keempat, menata taksonomi berpikir yang lebih fleksibel.

Aspek kedua dalam hal menata keselarasan KD berdapak langsung kepada mata pelajaran sejarah. Medio tahun 2016 keluarlah Permendikbud No. 24 Tahun 2016 menjelaskan bahawasanya mata pelajaran Sejarah Indonesia di SMK masih tetap 2 jam pelajaran perminggu namun hanya diberikan di kelas X dan XI saja. Hal ini menjadi permasalahan di lapangan dalam hal implementasi Kurikulum 2013 revisi 2016, kekisruhan ini dikarenakan pemerintah tidak memberikan ramburambu yang jelas dalam pelaksanaan kurikulum revisi di SMK untuk mata pelajaran Sejarah Indonesia karena perubahan struktur kurikulum untuk Sejarah Indonesia tidak dibarengi dengan perangkat yang lengkap. Kementerian Pendidikan dan Kebudayaan mengeluarkan kebijakan kurikulum revisi namun Kompetensi Inti dan Kompetensi Dasar (KI-KD) tidak ada perubahan dan masih disamakan dengan jenjang SMA/MA sederajat. Hal ini tentu saja menjadi masalah karena secara tidak langsung materi dalam mata pelajaran sejarah terpotong begitu saja di kelas XI, karena di kelas XII peserta didik tidak mendapatkan mata pelajaran Sejarah Indonesia.

Struktur kurikulum SMK/MAK masih terdapat kesamaan dengan struktur kurikulum pada Permendikbud No. 70 Tahun 2013 yakni terbaginya mata pelajaran dalam tiga kelompok, yaitu Kelompok A (Wajib), Kelompok B (Wajib), dan Kelompok C (Peminatan). Namun hasil dari revisi pemerintah terhadap Kurikulum 2013 untuk SMK membuat 
alokasi waktu untuk mata pelajaran Sejarah Indonesia berkurang dari yang awlanya 216 jam pelajaran berkurang menjadi 144 jam pelajaran yakni 2 jam pelajaran per minggu dan hanya diberikan di kelas X dan XI. Jelas terdapat alasan mengenai berkurangnya alokasi jam untuk Sejarah Indonesia di SMK/MAK, karena pemerintah pada tahun 2016 sedang menggencarkan program revitalisasi SMK/MAK yang mana ini berimbas ditambahnya alokasi jam mata pelajaran Kelompok C (Peminatan) dan mengurangi jam pada kelompok A dan B termasuk Sejarah Indonesia didalamnya.

Selain hal tersebut di atas, berubahnya Kurikulum 2013 revisi 2016 membawa dampak terhadap organsasi materi untuk kelas XI (sebelas). Pada Kurikulum 2013 awal KD untuk kelas XI yang awalnya 11 KD mengalami perubahan menjadi $10 \mathrm{KD}$, namun pengurangan KD ini justru menambah materi yang sebelumnya tidak ada pada Kurikulum 2013 awal yakni materi "Pendudukan Jepang". Untuk lebih jelasnya disajikan dalam tabel dibawah ini:

Tabel 2. Organisasi Materi Berdasarkan KI-KD Kurikulum 2013 Revisi 2016

\begin{tabular}{|c|c|}
\hline Kelas X & Kelas XI \\
\hline KI 3 berjumlah $8 \mathrm{KD}$ & KI 3 berjumlah $10 \mathrm{KD}$ \\
\hline KI 4 berjumlah $8 \mathrm{KD}$ & KI 4 berjumlah $10 \mathrm{KD}$ \\
\hline Materi: & Materi: \\
\hline 1. Konsep berpikir diakronik, sinkronik, & 1. Kolonialisme Barat di Indonesia \\
\hline 2. Masa praaksara & 3. Pendudukan Jepang di Indonesia \\
\hline 3. Masa Hindu-Buddha & 4. Proklamasi \\
\hline 4. Masa Kerajaan Islam & 5. Revolusi Kemerdekaan \\
\hline
\end{tabular}

Setelah mengalami revisi pada tahun 2016, guru Sejarah Indonesia yang pada awalnya diberikan beban formal untuk melakukan pembelajaran dan penilaian terhadap kompetensi sikap spiritual dan sikap sosial siswa. Kini, kompetensi sikap sosial dan spiritual tidak lagi diberikan secara intrakurikuler pada semua mata pelajaran, KI 1 dan KI 2 menjadi hidden curriculum dan hanya dibebankan kepada dua guru mata 
pelajaran saja yang bisa memberikan penilaian sikap siswa secara langsung, yaitu guru Pendidikan Agama-Budi Pekerti dan guru PPKn. Sedangkan guru lain di luar kedua mata pelajaran ini, dapat mengajarkan dan memberi nilai secara tidak langsung.

Perubahan ini menimbulkan kontra dikalangan guru Sejarah Indonesia yang mengajar di SMK, sudah sangat jelas perubahan ini memotong pelajaran sejarah sampai kelas XI tanpa ada penyesuaian dari segi KD (Wawancara Rohmatul Fajri, 21 November 2018; Ersontowi, 27 Juli 2019).

\section{Pelajaran Sejarah dalam Kurikulum 2013 revisi 2017}

Revisi Kurikulum 2013 pada tahun 2017 ini nampaknya hanya berlaku bagi jenjang SMK/MAK, berdasarkan Surat Keputusan Direktur Jenderal Pendidikan Dasar dan Menengah No. 180/D/KEP/KR/2017 disana menyebutkan bahwa Sejarah Indonesia dalam struktur kurikulum di SMK berkurang menjadi 108 jam atau 3JP x 2 semester artinya Sejarah Indonesia hanya diberikan kepada peserta didik pada jenjang kelas X saja. Berbeda dengan Permendikbud No. 24 tahun 2016 yang tidak mengatur mengenai KI-KD Sejarah Indonesia untuk SMK, pada SK Dirjen Dikdasmen mengatur KI-KD menjadi 2 KI dan 13 KD saja.

Sebagai gambaran, di bawah ini disajikan salah satu struktur kurikulum untuk kompetensi keahlian Bisnis Konstruksi dan Properti, hal ini tidaklah menjadi masalah karena jumlah jam Sejarah Indonesia sama semua untuk seluruh kompetensi keahlian. 


\begin{tabular}{|c|c|c|c|c|c|c|}
\hline \multirow{2}{*}{ No } & \multirow{2}{*}{ Mata Pelajaran } & \multicolumn{4}{|c|}{ Kelas } & \multirow{2}{*}{ Ket } \\
\hline & & $\mathrm{X}$ & $\mathrm{XI}$ & XII & XIII & \\
\hline 1. & $\begin{array}{l}\text { Pendidikan Agama dan } \\
\text { Budi Pekerti }\end{array}$ & $3 \mathrm{JP}$ & $3 \mathrm{JP}$ & $3 \mathrm{JP}$ & - & \\
\hline 2. & $\begin{array}{l}\text { PendidikanPancasila dan } \\
\text { Kewarganegaraan }\end{array}$ & $2 \mathrm{JP}$ & $2 \mathrm{JP}$ & $2 \mathrm{JP}$ & - & \\
\hline 3. & Bahasa Indonesia & $4 \mathrm{JP}$ & $3 \mathrm{JP}$ & $3 \mathrm{JP}$ & - & \\
\hline 4. & Matematika & $4 \mathrm{JP}$ & $4 \mathrm{JP}$ & $4 \mathrm{JP}$ & - & \\
\hline \multirow{3}{*}{5.} & \multicolumn{6}{|c|}{ Bahasa Inggris dan Bahasa Asing Lainnya* } \\
\hline & 1. Bahasa Inggris & $3 \mathrm{JP}$ & $3 \mathrm{JP}$ & $2 \mathrm{JP}$ & $2 \mathrm{JP}$ & \\
\hline & $\begin{array}{l}\text { 2. Bahasa Asing } \\
\text { Lainnya }\end{array}$ & - & - & $2 \mathrm{JP}$ & $2 \mathrm{JP}$ & \\
\hline 6. & Sejarah & $3 \mathrm{JP}$ & - & - & - & \\
\hline 7. & Seni Budaya & $3 \mathrm{JP}$ & - & - & - & \\
\hline 8. & $\begin{array}{l}\text { Pendidikan Jasmani, } \\
\text { Olahraga, dan Kesehatan }\end{array}$ & $2 \mathrm{JP}$ & $2 \mathrm{JP}$ & - & - & \\
\hline 9. & Peminatan Kejuruan & $22 \mathrm{JP}$ & $29 \mathrm{JP}$ & $30 \mathrm{JP}$ & $42 \mathrm{JP}$ & \\
\hline & Total JP Per Minggu & $46 \mathrm{JP}$ & $46 \mathrm{JP}$ & $46 \mathrm{JP}$ & $46 \mathrm{JP}$ & \\
\hline
\end{tabular}

Gambar 3. Struktur Kurikulum SMK/MAK

Berdasarkan SE Direktur PSMK No. 4540/D5.3/tu/2017

Dari gambar di atas, dapat dilihat bahwasanya struktur kurikulum SMK/MAK untuk mata pelajaran Sejarah Indonesia benar-benar berubah total dari Kurikulum 2013 awal maupun Kurikulum 2013 revisi 2016. Nama mata pelajaran Sejarah Indonesia berubah nomenklatur menjadi Sejarah. Hasil revisi tahun 2017 untuk jenjang SMK membuat alokasi waktu untuk mata pelajaran Sejarah pun berkurang kembali dari yang awalnya 144 jam pelajaran berkurang menjadi 108 jam pelajaran yakni 3 jam pelajaran per minggu dan hanya diberikan di kelas $X$ saja. Pengorganisasian materipun otomatis mengalami perubahan, dari yang awalnya diajarkan di kelas $\mathrm{X}$ dan $\mathrm{XI}$, dengan aturan baru ini menjadi hanya di kelas $\mathrm{X}$ dengan dengan total $13 \mathrm{KD}$.

13 KD yang dirancang oleh pemerintah rupanya mencakup semua materi dari kelas X-XII pada kurikulum 2013 awal dengan pemadatan materi dan lebih mengedepankan makna bukan lagi hapalan periodesasi. 
Tabel 2. Organisasi Materi Berdasarkan KI-KD Kurikulum 2013 Revisi 2017 Kelas X

KI 3 berjumlah $13 \mathrm{KD}$

KI 4 berjumlah $13 \mathrm{KD}$

Materi:

1. Konsep berpikir diakronik, sinkronik, ruang, waktu dalam sejarah

2. Masa praaksara

3. Masa Kerajaan Hindu-Buddha

4. Masa Kerajaan-kerajaan Islam

5. Kolonialisme Barat di Indonesia

6. Pergerakan Nasional

7. Proklamasi

8. Revolusi Kemerdekaan

9. Disintegrasi Bangsa

10. Demokrasi Liberal \& Demokrasi Terpimpin

11. Orde Baru \& Reformasi

12. Peran Indonesia dalam perdamaian dunia Pengembangan IPTEK dari Kemerdekaan-Reformasi

Apabila dilihat dari organisasi materi berdasarkan KI-KD yang dikeluarkan oleh pemerintah melalui SK Dirjen Dikdasmen No. 180/D/KEP/KR/2017, nampak sangat padat sekali materi yang harus diberikan oleh guru kepada peserta didik, walaupun pemerintah sudah memberikan arah bahwasanya bukanlah pengetahuan fakta yang perlu diajarkan melainkan nilai yang terkandung dari setiap peristiwa. Namun fakta yang terjadi di lapangan banyak guru yang mengeluh akan materi sejarah yang padat dan hanya satu tahun diberikan di kelas $X$ (Wawancara Rohmatul Fajri, 21 November 2018; Ersontowi, 27 Juli 2019).

Ada hal yang menarik apabila dianalisis lebih jauh, Surat Edaran Direktur Pembinaan SMK No. 4540/D5.3/tu/2017 tentang pelaksanaan Kurikulum SMK mengalahkan peraturan diatasnya yakni Permendikbud No. 60 Tahun 2014 mengenai struktur Kurikulum SMK dan MAK yang belum dicabut. Dengan diterapkannya SE Direktur PSMK membuat mata pelajaran Sejarah Indonesia untuk seluruh Bidang Keahlian dan 
Kompetensi Keahlian hanya diajarkan di kelas X saja dengan total alokasi waktu 108 jam pelajaran tanpa ada pembahasan lebih lanjut di Puskurbuk.

\section{PEMBAHASAN}

\section{Menyikapi Perubahan Kurikulum Sejarah Indonesia di SMK}

Perubahan kurikulum merupakan sebuah hal yang wajar dalam dunia pendidikan untuk menjawab perubahan dunia yang terjadi, justru menjadi janggal ketika tidak adanya evaluasi dari kurikulum yang sedang dijalankan. Perubahan pada Kurikulum 2013 juga yang membuat mata pelajaran Sejarah Indonesia menjadi semakin berkurang jelan merupakan bagian dari representasi sebuah kebijakan pemerintah. Perubahan yang terjadi dan berdampak langsung untuk Sejarah Indonesia di SMK merupakan kebijakan publik yang berkaitan dengan kajian pendidikan dan kurikulum tidak akan pernah lepas dari politik kekuasaan, kebijakan ini dengan sendirinya akan berimplikasi pada kehidupan berbangsa dan bernegara dimasa kini maupun massa yang akan datang.

Perubahan dalam Sejarah Indonesia sudah barang tentu merupakan tindakan politik kompromistis antara eksekutif dalam hal ini diwakili oleh Kementerian Pendidikan dan Kebudayaan dan legislatif dalam hal ini sebagai representasi dari masyarakat yang dipilih melalui proses pemilihan umum yang demokratis (Zulkarnain, 2018). Terdapat pertanyaan menggelitik, apakah antara pembuat kebijakan dan pengguna kebijakan sudah sinkron dan saling terkait satu dengan yang lainnya? Hal ini menjadi penting dan berkaitan erat karena kurikulum tidak mungkin menjadi sebuah kebijakan publik apabila tidak mendapat dukungan politik.

Mata pelajaran sejarah memuat pelajaran penting bagi umat manusia dari masa ke masa. Posisi penting yang dimiliki oleh mata pelajaran sejarah ini dilandasi oleh kenyataan bahwa mempelajari masa lalu 
mampu menjadikan pedoman dalam menjalani kehidupan masa kini dan masa yang akan datang. Pentingnya keberadaan mata pelajaran sejarah dalam kurikulum SMK/MAK juga tidak terlepas dari landasan bahwa sejarah mampu mengembangkan potensi peserta didik untuk menjadi manusia seutuhnya (Widja, 2018; Suswandari, 2010; Hasan, 2006).

Apabila melihat dari hasil analisis yang sudah dipaparkan di atas, terdapat penyimpangan secara regulasi pada penerapan Kurikulum 2013 untuk mata pelajaran Sejarah pada jenjang SMK/MAK. Pertama, bahwa belum adanya landasan hukum yang menyatakan bahwa Permendikbud No. 60 tahun 2014 dinyatakan dicabut dan tidak berlaku lagi yang pada akhirnya membuat mata pelajaran Sejarah berkuang. Kedua, regulasi yang keluar setelah diberlakukannya Permendikbud No. 60 tahun 2014 dikeluarkan oleh Dirjen Dikdasmen yang secara tataran hukum memiliki kekuatan lebih rendah dari peraturan menteri.

Ketiga, regulasi yang berupa Surat Keputusan Dirjen Dikdasmen hanya berlaku pada mata pelajaran kejuruan, sedangkan mata pelajaran Sejarah Indonesia merupakan mata pelajaran kelompok A (umum) yang menjadi wewenang Pusat Kurikulum dan Perbukuan. Keempat, mata pelajaran Sejarah Indonesia di SMK/MAK merupakan mata pelajaran wajib dalam kepentingan tujuan pendidikan nasional dalam rangka pembentukan karakter bangsa. Kelima, tidak adanya koordinasi antara pemegang kebijakan yang berdampak pada regulasi yang dikeluarkan saling tumpang tindih.

Terlepas dari adaya penyimpangan dalam pengeluaran regulasi Kurikulum 2013 di SMK/MAK untuk mata pelajaran Sejarah Indonesia, namun dalam tataran praktisnya masih sangat dibutuhkan lebih-lebih apabila dikaitkan dengan kebutuhan praktis masa depan (Zed, 2018). 
Sejarah tetap diperlukan dalam kehidupan masyarakat global kaitannya dengan penanaman nilai sadar sejarah untuk menumbuhkan kemampuan intelektual yang kritis dan tajam dalam menghadapi situasi yang terus berubah ini. Pemahaman sejarah diyakini dapat memperkokoh tentang kehidupan masa kini. Dengan kata lain, belajar dari masa lampau untuk masa kini dan masa yang akan datang.

Berkaitan dengan hal tersebut di atas, tentunya harus ada perubahan paradigma pembelajaran sejarah dari situasi linier hapalan ke arah pemahaman makna moral kesejarahan dan nilai-nilai yang terkandung dari setiap peristiwa yang terjadi. Keadaan ini memerlukan profesi bermakna dari guru sejarah yang harus benar-benar dari latar belakang pendidikan sejarah, termasuk di dalamnya perangkat pembelajaran di sekolah dan lingkup pendidikan yang lebih luas.

Pemerintah beralasan bahwa pengurangan jam ini karena pembelajaran sejarah di SMK tidak berpaku pada pembelajaran yang berdasar episode kesejarahan (Kompas, 25 September 2019). Sedangkan dari pihak guru sejarah menganggap bahwa posisi mata pelajaran sejarah wajib diberikan kepada seluruh peserta didik disemua kelas pada seluruh jenjang pendidikan (SMA/MA/SMK/MAK) dalam rangka penguatan karakter bangsa. Sungguh ironis apabila pemerintah ingin meningkatkan keterampilan siswa SMK dengan mengabaikan pelajaran sejarah yang nantinya hanya menjadi robot hidup industri (Wawancara Wawan Darmawan, 7 Juli 2018).

Hamid Hasan memberikan pandangan terkait organisasi konten kurikulum pendidikan sejarah yang tidak harus bersifat progresif, melainkan harus menggunakan pendekatan yang dinamakan "expanding community approach" (Hasan, 2006). Dengan pendekatan tersebut maka 
nantinya peserta didik belajar peristiwa sejarah dimulai dari yang paling dekat dengan lingkungannya ke lingkungan yang paling jauh. Dengan demikian maka kurikulum pendidikan sejarah memberikan kesempatan kepada peserta didik untuk melakukan kajian dalam berbagai tema sejarah dan memiliki kesempatan menggunakan kemampuan sejarah dalam realita kehidupan kesehariannya tidak lagi hanya menghapal rentetan peristiwa saja.

Mata pelajaran Sejarah Indonesia pada jenjang SMK/MAK perlu dikaji ulang agar sesuai dengan target dan tujuan pendidikan nasional. Pada saat yang bersamaan mata pelajaran Sejarah Indonesia mampu memenuhi kebutuhan pemenuhan wawasan kebangsaan siswa vokasi. Sejarah merupakan pemahaman akan identitas bangsa dan perkembangannya sepanjang zaman yang menjadi landasan berpikir masyarakat Indonesia.

\section{KESIMPULAN}

Sejak awal penerapan Kurikulum 2013 pada tahun pelajaran 2013/2014 mata pelajaran Sejarah Indonesia mendapatkan porsi yang cukup besar baik di jenjang SMK/MAK apalagi di SMA/MA. Namun tidak lama setelah penerapan Kurikulum 2013 pemerintah melakukan perbaikan atas Kurikulum yang sudah berjalan dengan dalih tuntutan jaman.

Dampak dari revisi Kurikulum 2013 pada tahun 2016 atau lebih dikenal dengan Kurikulum 2013 revisi 2016 membuat mata pelajaran Sejarah Indonesia di jenjang SMK/MAK mengalami perubahan yang cukup mengejutkan bagi kalangan guru sejarah di lapangan. Hal ini dikarenakan pemerintah hanya memberikan pelajaran Sejarah Indonesia di kelas $X$ dan XI tanpa adanya perubahan KI-KD dan membuat materi 
pelajaran sejarah otomatis terpotong di kelas XI, peserta didik mendapatkan pemahaman yang tidak utuh akan sejarah yang sedang ia pelajari di bangku SMK/MAK.

Setahun kemudian, dengan dalih revitalisasi SMK dan diterapkannya kerjasama dengan DU-DI mata pelajaran Sejarah Indonesia di SMK/MAK mengalani perubahan yang cukup signifikan, dari pertama Kurikulum 2013 mendapatkan alokasi 216 JP, berubah menjadi 144 JP dan di tahun 2017 Sejarah Indonesia hanya mendapatkan alokasi wkatu 108 JP dan hanya diajarkan selama dua semester di kelas $X$ dengan pemadatan materi dari kelas $\mathrm{X}$ hingga kelas XII.

Pelajaran Sejarah Indonesia di SMK mengalami dua pandangan yang saling bertentangan dalam waktu yang sama. Disatu sisi memiliki peran strategis terutama sebagai sarana pewarisan budaya (cultural transmission), penguatan jati diri generasi penerus, sumber edukasi integrasi bangsa. Namun sisi lain pelajaran Sejarah Indonesia dianggap tidak penting mata pelajaran utama (peminatan). Dengan diterapkannya Kurikulum 2013, pendidikan sejarah tentunya dituntut untuk melakukan pembaruan dalam pengajaran di sekolah, termasuk memperbaharui cara pandang tentang konsep sejarah, content (isi atau bahan ajar sejarah), metode mengajar, dan bahkan juga penilaian (assessement) dalam pembelajaran sejarah. Konsep berfikir sejarah dalam hal ini merupakan bagian dari upaya untuk meningkatkan semangat berfikir kritis dalam sejarah, sehingga pembelajaran sejarah semakin dekat dengan semangat ilmiah. Hal tersebutlah yang seharusnya dilakukan agar tidak ada lagi pandangan yang negatif untuk pelajaran sejarah untuk di setiap jenjang terlebih jenjang SMK/MAK yang memang memiliki karakteristik berbeda dengan SMA/MA. 


\section{REFERENSI}

[1] Agustinova, D. (2018). Penerapan Kurikulum 2013 Pada Mata Pelajaran Sejarah Pada Sekolah Menengah Atas. ISTORIA: Jurnal Pendidikan dan Ilmu Sejarah.Vol. 4 No. 1.

[2] Alfian, M. (2011). "Pendidikan Sejarah dan Permasalahan yang Dihadapi". Khazanah Pendidikan, III(2), 1-8.

[3] Djojonegoro, W. (1999). Pengembangan Sumber Daya Manusia Melalui Sekolah Menengah Kejuruan. Jakarta: Balai Pustaka.

[4] Evans, R. N., \& Edwin, L. H. (1978). Foundation of Vocational Education. Columbus: Charles E. Merril Publishing Company.

[5] Gottschalk, L. (1975). Mengerti Sejarah. Jakarta: Universitas Indonesia.

[6] Hasan, S. H. (1994). Kurikulum Sejarah 1994: Pengertian, Landasan, Pemikiran dan Konsekwensi. Bandung: Makalah Pada Seminar Jurusan Pendidikan Sejarah FPIPS UPI.

[7] Hasan, S. H. (2006). Pembelajaran Sejarah Yang Mencerdaskan: Mungkinkah?, Pendidikan Sejarah, Universitas Pendidikan Indonesia.

[8] Sardiman. (2015). "Menakar Posisi Sejarah Indonesia pada Kurikulum 2013". ISTORIA, 11(2), 1-13.

[9] Sjamsuddin, H. (2012). Metodologi Sejarah. Yogjakarta: Ombak.

[10] Sulaiman, S. (2012). "Pendekatan Konsep Dalam Pembelajaran Sejarah". Lontar, 9(1), 9-21.

[11] Suswandari. (2010). "Paradigma Pendidikan Sejarah Dalam Menghadapi Tantagan Masa Depan". Cakrawala Pendidikan, XXIX(1), 27-42.

[12] Widja, I. G. (2018). “Pembelajaran Sejrah Yang Mencerdaskan: Suatu Alternatif Menghadapi Tantangan dan Tuntutan Jaman Yang Berubah". Jurnal Pendidikan Sejarah Indonesia, 1(1), 117-134.

[13] Wijayanti, Y. (2017). "Peranan Penting Sejarah Lokal dalam Kurikulum di Sekolah Menengah Atas". Jurnal Artefak, 4(1), 5360. 
[14] Zed, M. (2018). “Tentang Konsep Berfikir Sejarah". Lensa Budaya, 13(1), 54-60.

[15] Zulkarnain. (2018). “Kebijakan Kurikulum Pendidikan Sejarah Masa Reformasi di SMA". ISTORIA, 14(2), 1-14.

\section{Dokumen dan Surat Kabar}

[16] Keputusan Direktur Jenderal Pendidikan Dasar dan Menengah Nomor 130/D/KEP/KR/2017 Tentang Struktur Kurikulum Pendidikan Menengah Kejuruan.

[17] Peraturan Menteri Pendidikan dan Kebudayaan Republik Indonesia Nomor 70 Tahun 2013 Tentang Kerangka Dasar dan Struktur Kurikulum Sekolah Menengah Kejuruan/Madrasah Aliyah Kejuruan.

[18] Peraturan Menteri Pendidikan dan Kebudayaan Republik Indonesia Nomor 60 Tahun 2014 Tentang Kurikulum 2013 Sekolah Menengah Kejuruan/Madrasah Aliyah Kejuruan.

[19] Peraturan Menteri Pendidikan dan Kebudayaan Republik Indonesia Nomor 24 Tahun 2016 Tentang Kompetensi Inti dan Kompetensi Dasar Pelajaran Pada Kurikulum 2013 Pada Pendidikan Dasar dan Pendidikan Menengah.

[20] Surat Edaran Direktur Pembinaan SMK No. 4540/D5.3/tu/2017 Tentang Pelaksanaan Kurikulum SMK.

[21] Kompas. Kaji Pelajaran Sejarah di SMK. Rabu, 25 September 2019.

\section{Wawancara}

[22] Wawan Darmawan, Dosen Pendidikan Sejarah Universitas Pendidikan Indonesia/Pengembang Kurikulum 2013, 7 Juli 2018.

[23] Rohmatul Fajri, Ketua MGMP Provinsi Banten, 21 November 2018.

[24] Ersontowi, Ketua MGMP Sejarah Bandar Lampung, 27 Juli 2019. 